\title{
Economic Ordering Policy for VAR Deterioration Model with Non-stationary Two-warehouse Inventory and Demand
}

\author{
Abdullah M. A. Alshami*1 and Aniket A. Muley ${ }^{2}$ \\ ${ }^{1}$ Thamar University, Thamar, Yemen, Educational Faculty, Mathematics Department \\ ${ }^{2}$ Swami Ramanand Teerth Marathwada University, Nanded, India \\ Mathematical School of Sciences, Statistics 431606 Maharashtra, India \\ Email: balshami11@gmail.com, aniket.muley@gmail.com
}

\begin{abstract}
This paper adopts the two-warehouse inventory, determination on the first run-time and VAR (Vector Auto Regression) deterioration model. The optimal EOQ in the interval of the finite horizon is determined under critical considerations. The non-stationary two-warehouse inventory, i.e. the inventory and initial inventory are non-stationary at level, but stationary after lag difference similar to demand (demand and initial demand). The output of the proposed model represented the optimal order quantity and optimal first run-time, the optimal total cost as integration of first order with the significant trend and intercept. The optimal demand is decreased during more risk as a deterioration variable to reduce the quantity in the stock. The initial demand is stationary after a first lag and the demand is stationary.

Keywords: initial inventory; optimal of first run-time; EOQ (Economic Ordering Quantity); total cost function (TC).
\end{abstract}

\begin{abstract}
Abstrak
Penelitian ini mengadopsi inventori dengan dua gudang penyimpanan, penentuan pada waktu run (runtime) awal, dan model deteriorating VAR (Vector Auto Regression). Nilai optimal EOQ dalam interval horizon berhingga ditentukan dengan pertimbangan kritis. Inventori dengan dua gedung yang tidak stasioner, yaitu inventori dan inventori awal tidak stasioner pada level, tetapi stasioner setelah perbedaan lag seperti halnya pada permintaan (permintaan dan permintaan awal). Hasil dari model yang diajukan menunjukkan nilai orde yang optimal dan waktu run awal yang optimal, total biaya optimal sebagai integrasi dari orde pertama dengan tren dan intercept yang signifikan. Permintaan optimal mengalami penurunan ketika lebih banyak risiko sebagai variabel deteroriating untuk mengurangi jumlah dalam stok. Permintaan awal menunjukkan stasioner setelah perbedaan lag pertama dan permintaan juga stasioner.

Kata kunci: inventori awal; optimal run-time awal; EOQ (Economic Ordering Quantity); fungsi biaya total.
\end{abstract}

\section{INTRODUCTION}

Many types of researchers developed the inventory model, but this paper investigated the inventory model by the new assumptions as of the VAR (Vector Auto Regression) deterioration model 
and non-stationary inventory and initial inventory model. Maiti [1] developed a fuzzy model for deteriorating multi-outlet by applying triangular fuzzy. Chung et al. [2] investigated the model with permissible delay in payment under providing a discount in cash. Pal et al. [3] deals with the price and dependent demand in stock with permissible in delay in payment. Palanivel and Uthayakumar [4] developed the deteriorating model under new assumptions as price and dependent demand in the advertisement but in the output of the model in numerical analysis, the total cost decreased when the deterioration rate increased that is not supported by the inventory theory as Pal et al. [3]. Pal et al. [5] represented the EPQ under constant production across the year, fuzzy demand, and nonlinear deterioration. Omprakash et al. [6] attempted a model for the policy of the retailer's inventory to minimize the total cost to the retailer's inventory but the movement in the output is slow especially for the total cost. Jolai et al. [7] the framework of optimization is represented to optimize the production under variable deterioration. Neetu and Tomer [8] the inflation is considered as a variable in the deteriorating inventory and demand as the price of selling function. Tiwari et al. [9] developed the model through new consideration to the two-echelon supply chain; demand is non-constant as function in selling price. Tripathi and Kaur [10] investigated the deteriorating items by linear timedependent deterioration and demand. In this paper, we propose a model to handle the inventory under the VAR (Vector Auto Regression) deterioration model, non-stationary demands to determine the optimal first run-time and total cost, EOQ (Economic Order Quantity) also, reactivation of the output of the assumed model. The model in this paper used when the industry has stocked with two sub-stocks for the single items.

\section{MATERIAL AND METHOD}

\subsection{Assumptions and notions}

\subsubsection{Assumptions}

The mathematical model is developed within assumptions

1) The planning horizon is finite.

2) Single item inventory control.

3) The demand is non-stationary.

4) Initial demand is non-stationary at level but stationary at lag $=1$.

5) Deterioration is estimated by $\operatorname{VAR}(2,2)$ model as $\theta=a_{1} \theta(-1)+a_{2} \theta(-2)+b_{1} \theta_{0}(-1)+$ $b_{2} \theta_{0}(-2)+\epsilon$ where $a_{1}, a_{2}, b_{1}, b_{2}$ are real constants, $\epsilon$ is an error.

6) Initial deterioration is stationary over time.

7) There is no replacement or repair of deterioration items during the supposed period.

8) The shortage is not allowed.

9) The lead time is zero.

10) The inventory level at the end of the planning horizon is zero

11) The cost factors are deterministic.

\subsubsection{Notations}

$Q_{1}=$ The order quantity in stock within $\left(0, t_{1}\right)$.

$Q_{0}=$ The order quantity which is in stock within $\left(0, t_{1}\right)$.

$Q_{S}=$ The difference of order quantity which is in stock within $\left(0, t_{1}\right)$.

$T C=$ The total relevant cost $\left(0, t_{1}\right)$. 


\subsection{Parameters}

The mathematical model is representing the following parameters

$A=$ The fixed ordering cost per replenishment $\$$ /order.

$C=$ The unit purchasing price at time zero $\$$ /order.

$D_{1} \quad=$ The demand per unit time for $I_{1}(t)$.

$D_{0} \quad=$ The initial demand per unit time for $I_{0}(t)$.

$B_{0} \quad=$ positive real constant, $B_{0}>0$.

$B_{1} \quad=$ positive real constant, $B_{1}>0$.

$I_{0}(t)=$ The initial inventory level at $\left(0, t_{1}\right)$.

$I_{1}(t)=$ The inventory level at time during $\left(0, t_{1}\right)$.

$I_{h} \quad=$ The interest charged per \$per unit by the supplier.

$t_{1}=$ The first run time of each replenishment cycle for an emergency order.

$\theta=$ Deterioration units/unit time.

$\theta_{0} \quad=$ Initial deterioration units/unit time which is caused in $\theta$.

\section{MATHEMATICAL MODEL}

Let $I_{1}(t)$ is the inventory level at any time $t, 0 \leq t \leq t_{1}$, Depletion due to demand within first component interval $0 \leq t \leq t_{1}$. The $\frac{d I_{1}(t)}{d t}$ satisfied the Eq. (1) that describes the instantaneous state of $I_{1}(t)$ over the open interval $\left(0, t_{1}\right)$ is given by:

$$
\begin{aligned}
& \frac{d I_{1}(t)}{d t}=\theta \frac{d I_{0}(t)}{d t}+B_{0} D_{0}+B_{1} D_{1}, B_{0} D_{0}>0,0 \leq t \leq t_{1}, 0 \leq \theta \leq 1, \\
& I_{1}(t)-\theta I_{0}(t)=\int_{t}^{t_{1}}\left(B_{0} D_{0}+B_{1} D_{1}\right) d u=\left(B_{0} D_{0}+B_{1} D_{1}\right)\left(t_{1}-t\right) .
\end{aligned}
$$

Let $I_{0}(t)$ is initial of the inventory level at any time $t, 0 \leq t \leq t_{1}$. Depletion due to initial demand within component interval $t_{1} \leq t \leq T$ and there is initial deterioration. The first-order differential equation Eq. (2) that describes the instantaneous state of $I_{0}(t)$ over the open interval $\left(0, t_{1}\right)$ is given by

$$
\frac{d I_{0}(t)}{d t}+\theta_{0} I_{0}(t)=-D_{0}, 0 \leq t \leq t_{1}
$$

where $I_{0}\left(t_{1}\right)=0$ for equation of number. $I_{0}(t)=I_{01}(t) \int_{t}^{t_{1}} D_{0} e^{\theta_{0} u^{2}} d u=\frac{D_{0}}{\theta_{0}}\left(e^{\theta_{0}\left(t_{1}-t\right)}-\right.$ $1), I_{01}(t)=e^{-\theta_{0} t}$, and $I_{0}(0)=\frac{D_{0}}{\theta_{0}}\left(e^{\theta_{0} t_{1}}-1\right), Q_{0}=\frac{D_{0}}{\theta_{0}}\left(e^{\theta_{0} t_{1}}-1\right)$.

According to Eq. (2) the inventory level is given as $I_{1}(t)=\left(B_{0} D_{0}+B_{1} D_{1}\right)\left(t_{1}-t\right)+$ $\frac{\theta D_{0}}{\theta_{0}}\left(e^{\theta_{0}\left(t_{1}-t\right)}-1\right)$, and $Q_{1}=\left(B_{0} D_{0}+B_{1} D_{1}\right) t_{1}+\frac{\theta D_{0}}{\theta_{0}}\left(e^{\theta_{0} t_{1}}-1\right)$.

\subsection{Fixed ordering cost}

We assumed that the fixed ordering cost over the planning horizon $\left(0, t_{1}\right)$ consideration is: $T C_{A}=A$. 


\subsection{Purchasing cost}

The purchasing cost of calculated as $T C_{P}=C\left[\left(B_{0} D_{0}+B_{1} D_{1}\right) t_{1}+\frac{\theta D_{0}}{\theta_{0}}\left(e^{\theta_{0} t_{1}}-1\right)\right]$.

\subsection{Holding cost excluding interest cost}

The average inventory quantity is used to obtain holding cost

$$
\begin{gathered}
\bar{I}=\int_{0}^{t_{1}} I_{1}(t) d t=\int_{0}^{t_{1}}\left(\alpha B_{0} D_{0}+B_{1} D_{1}\right) t_{1}+\frac{\theta D_{0}}{\theta_{0}}\left(e^{\theta_{0} t_{1}}-1\right) d t \\
=\frac{\left(B_{0} D_{0}+B_{1} D_{1}\right) t_{1}^{2}}{2}+\frac{\theta D_{0}}{\theta_{0}^{2}}\left(e^{\theta_{0} t_{1}}-\theta_{0} t_{1}-1\right) . \\
T C_{h}=I_{h}\left[\frac{\left(B_{0} D_{0}+B_{1} D_{1}\right) t_{1}^{2}}{2}+\frac{\theta D_{0}}{\theta_{0}}\left(e^{\theta_{0} t_{1}}-1\right)\right], \\
T C=T C_{A}+T C_{h}+T C_{P} .
\end{gathered}
$$

Then $T C=\left[A+C\left[\left(B_{0} D_{0}+B_{1} D_{1}\right) t_{1}+\frac{\theta D_{0}}{\theta_{0}}\left(e^{\theta_{0} t_{1}}-1\right)\right]+I_{h}\left[\frac{\left(B_{0} D_{0}+B_{1} D_{1}\right) t_{1}{ }^{2}}{2}+\frac{\theta D_{0}}{\theta_{0}}\left(e^{\theta_{0} t_{1}}-1\right)\right]\right.$.

\subsection{Economic Order Quantity}

To find optimal run-time by minimizing the total cost function we found-out the optimal demand and optimal deterioration as the following

$$
\begin{aligned}
T C=\left[\frac{1}{t_{1}}\right][A+C & {\left[\left(B_{0} D_{0}+B_{1} D_{1}\right) t_{1}+\frac{\theta D_{0}}{\theta_{0}}\left(e^{\theta_{0} t_{1}}-1\right)\right]+I_{h}\left[\left(B_{0} D_{0}+B_{1} D_{1}\right) t_{1}+\frac{\theta D_{0}}{\theta_{0}{ }^{2}}\left(e^{\theta_{0} t_{1}}-\theta_{0} t_{1}-1\right)\right] } \\
\frac{d T C}{d t_{1}}= & {\left[-\frac{1}{t_{1}^{2}}\right]\left[A+C\left[\left(B_{0} D_{0}+B_{1} D_{1}\right) t_{1}+\frac{\theta D_{0}}{\theta_{0}}\left(e^{\theta_{0} t_{1}}-1\right)\right]+I_{h}\left[\frac{\left(B_{0} D_{0}+B_{1} D_{1}\right) t_{1}^{2}}{2}\right.\right.} \\
& \left.\left.+\frac{\theta D_{0}}{\theta_{0}^{2}}\left(e^{\theta_{0} t_{1}}-\theta_{0} t_{1}-1\right)\right]\right]+\left[\frac{1}{t_{1}}\right]\left[C\left[\left(B_{0} D_{0}+B_{1} D_{1}\right)+\theta D_{0} e^{\theta_{0} t_{1}}\right]\right. \\
& +I_{h}\left[\left(B_{0} D_{0}+B_{1} D_{1}\right) t_{1}+\frac{\theta D_{0}}{\theta_{0}^{2}}\left(e^{\theta_{0} t_{1}}-\theta_{0} t_{1}-1\right)\right]
\end{aligned}
$$

Let $\frac{d T C}{d t_{1}}=0$ to find the optimum total cost. Then $t_{1}^{*}=\sqrt{\frac{A}{\left[I_{h}\left(\frac{\left(B_{0} D_{0}+B_{1} D_{1}\right)}{2}+\theta D_{0}\right)+\theta_{0} C D_{0} \theta\right]}}$.

To test the $t_{1}{ }^{*}$ by using the second derivative, we found out that $\left.\frac{d^{2} T C}{d t_{1}{ }^{2}}\right|_{t=t_{1}{ }^{*}}=\frac{2 A}{t_{1}{ }^{3}}>0$ The total cost has minimum value at $t_{1}=t_{1}^{*}$.

\section{SENSITIVITY ANALYSIS}

Because the proposed model assumed the non-stationary demand and initial demand is nonstationary, the optimal order quantity and optimal first run-time, the optimal total cost is integrated at first order rank.

Example 1: We assumed the values of $B_{0}$ and $B_{1}$ as positive real are arbitrary, whether associated costs are too. We choose $A=50 \$, C=150 \$, I_{h}=10 \$, C_{s}=5 \$, B_{0}=0.2 \$, B_{1}=0.6$. SPSS 26 
Economic Ordering Policy for VAR Deterioration Model with Non-stationary Two-warehouse Inventory...

and EViews 10 software version are used in our analytics. The estimate $\operatorname{VAR}(2,2)$ model of deterioration is $\theta=0.557910880025 \theta(-1)+1.0865152812 \theta(-2)+0.26987524 \theta_{0}(-1)-$ $0.888957891765 \theta_{0}(-2)+0.068896924528$.

Table 1 . The sensitivity analysis.

\begin{tabular}{ccccccccc}
\hline$\theta$ & $\theta_{0}$ & $D_{0}$ & $D_{1}$ & $t_{1}^{*}$ & $\mathrm{EOQ}_{1}{ }^{*}$ & $\mathrm{EOQ}_{0}{ }^{*}$ & $\mathrm{Q}^{*}$ & $\mathrm{TC}^{*}$ \\
\hline 0.00007 & 0.000002 & 250 & 500 & 0.169022 & 59.1608 & 42.25561 & 16.90519 & 53094.23 \\
\hline 0.0007 & 0.0001 & 300 & 520 & 0.163864 & 60.99181 & 49.15923 & 11.83258 & 56441.42 \\
\hline 0.07 & 0.01 & 350 & 580 & 0.145195 & 64.25121 & 50.85503 & 13.39618 & 67025.49 \\
\hline 0.1 & 0.015 & 400 & 610 & 0.135582 & 65.89815 & 54.2878 & 11.61035 & 73577.24 \\
\hline 0.2 & 0.15 & 450 & 660 & 0.096629 & 55.72135 & 43.79948 & 11.92187 & 87251.55 \\
\hline 0.3 & 0.25 & 500 & 690 & 0.071814 & 47.78199 & 36.23143 & 11.55056 & 100687.4 \\
\hline 0.4 & 0.35 & 550 & 715 & 0.05514 & 41.9692 & 30.62162 & 11.34757 & 115233.4 \\
\hline 0.5 & 0.45 & 600 & 725 & 0.043832 & 37.60676 & 26.56018 & 11.04658 & 129972.5 \\
\hline 0.6 & 0.55 & 650 & 750 & 0.035817 & 34.8812 & 23.51202 & 11.36918 & 147601.1 \\
\hline 0.7 & 0.65 & 700 & 790 & 0.029949 & 33.20744 & 21.16967 & 12.03777 & 168112.7 \\
\hline 0.8 & 0.75 & 750 & 840 & 0.025521 & 32.15019 & 19.32473 & 12.82546 & 191052.8 \\
\hline 0.9 & 0.85 & 800 & 880 & 0.022093 & 31.25692 & 17.84121 & 13.41571 & 214617.4 \\
\hline 0.99 & 0.95 & 850 & 900 & 0.019471 & 30.36239 & 16.70473 & 13.65766 & 236611.1 \\
\hline
\end{tabular}

Table 2. The output of VAR model

$\begin{array}{lrr}\text { R-squared } & 0.998513 & 0.999119 \\ \text { Adj. R-squared } & 0.997522 & 0.998532 \\ \text { Sum sq. Resids } & 0.001595 & 0.000903 \\ \text { S.E. equation } & 0.016305 & 0.012266 \\ \text { F-statistic } & 1007.323 & 1701.074 \\ \text { Log likelihood } & 33.00468 & 36.13542 \\ \text { Akaike AIC } & -5.091759 & -5.660986 \\ \text { Schwarz SC } & -4.910898 & -5.480124\end{array}$

Table 3. The stationary test of EOQ1 at lag $=1$.

$\begin{array}{ccrrl} & & & \text { t-Statistic } & \text { Prob.* } \\ \text { Augmented Dickey-Fuller test statistic } & & -12.54827 & 0.0001 \\ \text { Test critical values: } & \text { 1\% level } & & -5.521860 & \\ & 5 \% \text { level } & & -4.107833 & \\ & 10 \% \text { level } & & -3.515047 & \\ \text { Variable } & \text { Coefficient } & \text { Std. Error } & \text { t-Statistic } & \text { Prob. } \\ \text { D(Q1*(-1)) } & -1.295156 & 0.103214 & -12.54827 & 0.0002 \\ \text { D(Q1*(-1),2) } & 0.215836 & 0.079825 & 2.703876 & 0.0539 \\ \text { D(Q1*(-2),2) } & 0.128770 & 0.080352 & 1.602569 & 0.1843 \\ \text { C } & -13.85027 & 1.107274 & -12.50844 & 0.0002 \\ \text { @TREND("1") } & 1.120089 & 0.121347 & 9.230464 & 0.0008\end{array}$


Table 4 . The stationary test of ' $\mathrm{TC}^{*}$ at lag $=1$.

\begin{tabular}{|c|c|c|c|c|}
\hline \multirow{2}{*}{\multicolumn{3}{|c|}{ Augmented Dickey-Fuller test statistic }} & t-Statistic & Prob.* \\
\hline & & & -4.247838 & 0.0429 \\
\hline \multirow[t]{3}{*}{ Test critical values: } & $1 \%$ level & & -5.521860 & \\
\hline & $5 \%$ level & & -4.107833 & \\
\hline & $10 \%$ level & & -3.515047 & \\
\hline Variable & Coefficient & Std. Error & t-Statistic & Prob. \\
\hline $\mathrm{D}\left(\mathrm{TC} \_(-1)\right)$ & -2.571953 & 0.605473 & -4.247838 & 0.0132 \\
\hline $\mathrm{D}\left(\mathrm{TC} \_(-1), 2\right)$ & 1.428007 & 0.480548 & 2.971622 & 0.0411 \\
\hline $\mathrm{D}\left(\mathrm{TC} \_(-2), 2\right)$ & 0.745408 & 0.248256 & 3.002583 & 0.0398 \\
\hline $\mathrm{C}$ & 6757.713 & 1347.356 & 5.015538 & 0.0074 \\
\hline @TREND("1") & 4181.679 & 1079.222 & 3.874715 & 0.0179 \\
\hline
\end{tabular}

Table 5. The stationary test of $\mathrm{t}_{1} *$ at lag $=1$

\begin{tabular}{|c|c|c|c|c|}
\hline \multicolumn{3}{|c|}{ Augmented Dickey-Fuller test statistic } & $\begin{array}{l}\mathrm{t}-\text { Statistic } \\
-8.343314\end{array}$ & $\begin{array}{l}\text { Prob.* } \\
0.0007\end{array}$ \\
\hline Test critical values: & $1 \%$ level & & -5.521860 & \\
\hline & $5 \%$ level & & -4.107833 & \\
\hline & $10 \%$ level & & -3.515047 & \\
\hline Variable & Coefficient & Std. Error & $\mathrm{t}$-Statistic & Prob. \\
\hline $\mathrm{D}\left(\mathrm{t}_{1} *(-1)\right)$ & -1.738569 & 0.208379 & -8.343314 & 0.0011 \\
\hline $\mathrm{D}\left(\mathrm{t}_{1} *(-1), 2\right)$ & 0.543628 & 0.165157 & 3.291575 & 0.0302 \\
\hline $\mathrm{D}\left(\mathrm{t}_{1} *(-2), 2\right)$ & 0.291296 & 0.117724 & 2.474387 & 0.0686 \\
\hline $\mathrm{C}$ & -0.067110 & 0.008077 & -8.308422 & 0.0011 \\
\hline @TREND("1") & 0.005395 & 0.000697 & 7.744471 & 0.0015 \\
\hline
\end{tabular}

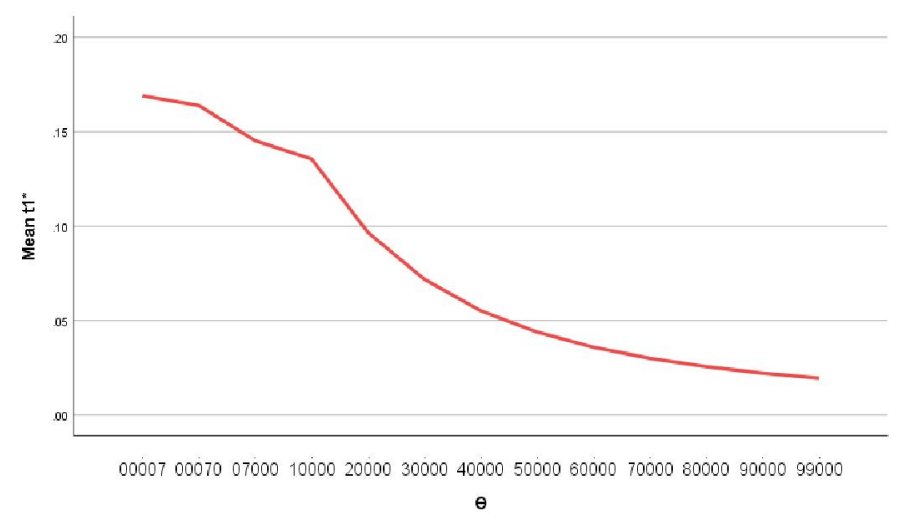

Figure 1. The deterioration in the stock versus optimal first-run time.

This paper adopted the vector autoregressive inventory model and applied the permissible range for considering the deterioration with the initial determination as $\operatorname{VAR}(2,2)$ model. The optimal first-run time, the optimal total cost across the period. The sensitivity analysis considered variable deterioration. The optimal first run-time decreased when the initial and deterioration, increased to satisfy the real situation as figure $1-2$. 
Economic Ordering Policy for VAR Deterioration Model with Non-stationary Two-warehouse Inventory...

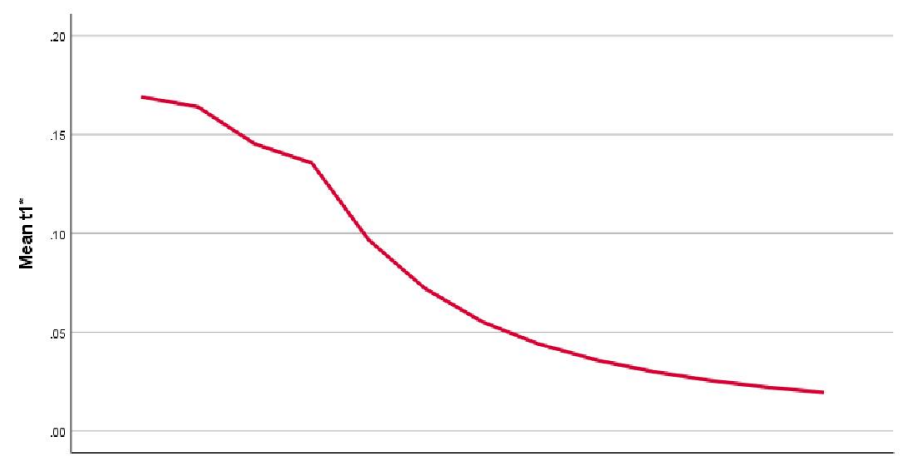

00000000100100001500150002500035000450005500065000750008500095000

$\theta 0$

Figure 2. The initial deterioration in the stock versus the optimal first-run time.

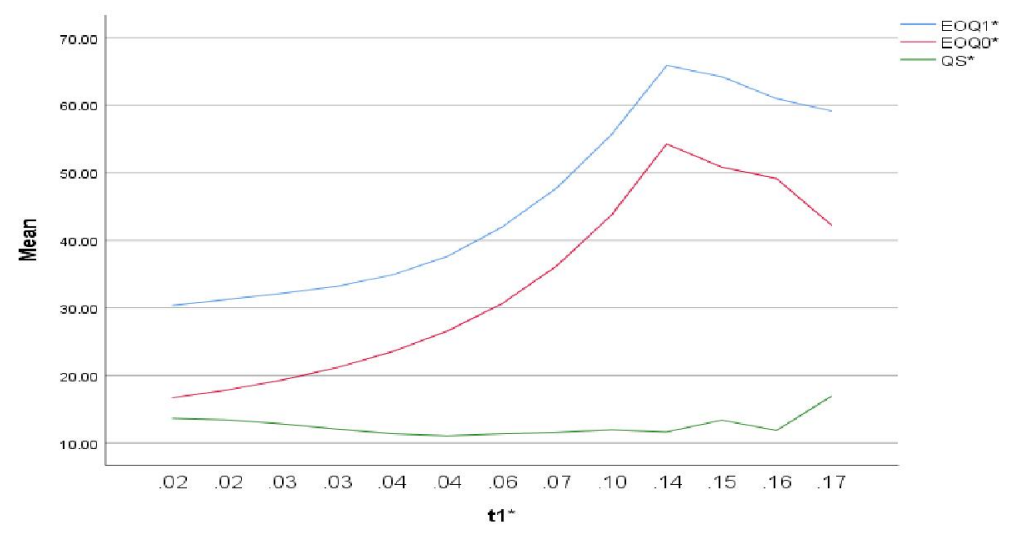

Figure 3. The optimal order quantity in the stock versus the optimal first-run time.

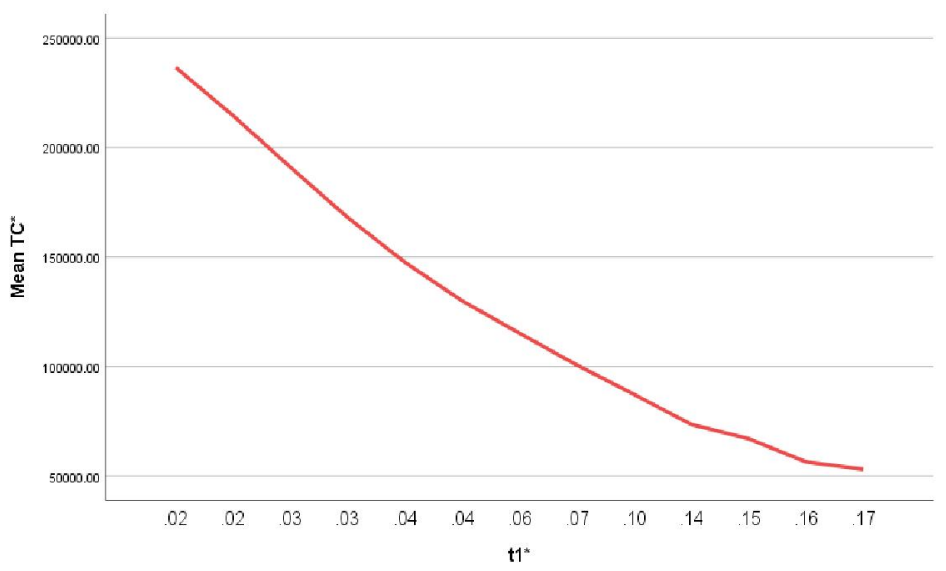

Figure 4. The optimal total cost versus optimal first-run time.

The optimal initial EOQ and EOQ decreased when the initial and deterioration, increased to satisfy the realistic situation, especially when initial deterioration equal to 0.015 or more that, deterioration equal to 0.1 or more than that as figure 3 . The optimal total cost increased when the first run-time increased and that expressed a positive relationship based on reality. The optimal of total 
cost increased when optimal of the first run-time was decreased as figure 4 . Because the deterioration risk is increasing. The output of the proposed model analyzed by Eviews 10 to check the stationary of EOQ as a table 3, the optimal total cost was stationary at lag=1 with significance trend and intercept as the table 4. Optimal first run-time was stationary at lag=1 with a significant trend and intercept as a table 5 .

\section{ACKNOWLEDGMENTS}

We would like to thank the authority in the journal for feedback and reviewing and full thanks to Thamer University in Yemen for financial supporting also SRTM University in India. This work is supported by the Mathematical School of Sciences, India to develop the inventory model of deteriorating items.

\section{REFERENCES}

[1] A. K. Maiti, "Multi-item fuzzy inventory model for deteriorating items in multi-outlet under single management," Journal of Management Analytics, vol. 7, pp. 44-68, 2020.

[2] K. -J. Chung, J. -J. Liao, S. -D. Lin, S. -T. Chuang and H. M. Srivastava, "The Inventory Model for Deteriorating Items under Conditions Involving Cash Discount and Trade Credit," Journal of Mathematics, vol. 7, no. 7, pp. 1-20, 2019.

[3] S. Pal, G. S. Mahapatra and G. P. Samanta, "An inventory model of price and stock dependent demand rate with deterioration under inflation and delay in payment," Int. J. System Assurance Engineering an Management, vol. 5, no. 4, pp. 591-601, 2014.

[4] M. Palanivel and R. Uthayakumar, "Finite horizon EOQ model for non-instantaneous deteriorating items with price and advertisement dependent demand and partial backlogging under inflation," International Journal of Systems Science, vol. 46, no. 10, pp. 1762-1773, 2013.

[5] S. Pal, G. S. Mahapatra and G. P. Samanta, "A production inventory model for deteriorating item with ramp type demand allowing inflation and shortages under fuzziness," Economic Modelling, Elsevier, vol. 46, no. (C), pp. 334-345, 2015.

[6] K. G. Omprakash, H. S. Nita and T. S. Kunal, "Supply chain inventory model for deteriorating items under two-level credit policy in declining market," Int. J. of Applied Management Science, vol. 3, no. 2, pp. 143-173, 2011.

[7] F. Jolai, R. Tavakkoli-Moghaddam, M. Rabbani and M. Sadoughian, "An economic production lot size model with deteriorating items, stock-dependent demand, inflation, and partial backlogging," Applied Mathematics and Computation, vol. 181, no. 1, pp. 380-389, 2006.

[8] Neetu and A. K. Tomer, "A Deteriorating Inventory Model Under Variable Inflation When Supplier Credits Linked to Order Quantity," Procedia Engineering, vol. 38, p. 1241 - 1263, 2012.

[9] S. Tiwari, C. K. Jaggi, M. Gupta and L. E. Cárdenas-Barrón, "Optimal pricing and lot-sizing policy for supply chain system with deteriorating items under limited storage capacity," International Journal of Production Economics, vol. 200, pp. 278-290, 2018.

[10] R. P. Tripathi and M. Kaur, "A linear time-dependent deteriorating inventory model with linearly time-dependent demand rate and inflation," Int. J. Computing Science and Mathematics, vol. 9, no. 4, pp. 352-364, 2018. 
Economic Ordering Policy for VAR Deterioration Model with Non-stationary Two-warehouse Inventory...

87 | InPrime: Indonesian Journal of Pure and Applied Mathematics 